\title{
IAMJ
}

INTERNATIONAL

AYURVEDIC

MEDICAL JOURNAL

Review Article

ISSN: 2320-5091

Impact Factor: 6.719

\section{A COMPREHENSIVE STUDY ON LOHITAKSHA MARMA}

\section{Rahul Kumar Gupta}

Assistant Professor, Dept of Rachna Sharir, Jammu Institute of Ayurveda \& Research, Nardani Raipur (Bantalab) Jammu-181123., India

Corresponding Author: rahulguptasdm@gmail.com

https://doi.org/10.46607/iamj2308122020

(Published online: December 2020)

Open Access

(C) International Ayurvedic Medical Journal, India 2020

Article Received: 12/11/2020 - Peer Reviewed: 16/11/2020 - Accepted for Publication: 20/11/2020

\section{A) Check for updates}

\section{ABSTRACT}

The Marma Vijnana (Science of vital points) has been dealt in Shareera Sthana of Ayurvedic texts like Sushruta Samhita (Textbook), Astanga Samgraha (Textbook) and Astanga Hridaya (Textbook). The references related to Marma are also available in Charaka Samhita. Almost all the texts of Ayurveda have mentioned the total number of Marma as 107. Out of these Lohitaksha Marma is considered under the Shakhagata Marma (vital points of the limb region). The concept of Marma is important in the clinical and surgical point of view. In this article an attempt is made to study the lohitaksha Marma and its Viddha Lakshana (Traumatic effect) by considering the related literature.

Keywords: Marma, Lohitaksha, Viddha, Shakha

\section{INTRODUCTION}

Marma point (Vital point) is defined as the site where there is confluence of structures like Mamsa (Muscular component), Sira (Vascular component), Snayu (Neuroconnective tissue component), Asthi (Sclerous component) and Sandhi (Articular component) and Prana (Life force) resides making it as its specific place. Knowledge of the Marma is described as half the knowledge of Shalyatantra (Science of surgery), as persons injured in the vital spot die immediately or suffer from unforeseen ailment which is life threating; if anyone survives by the efficiency of the physician, is sure to suffer from deformities. Injury to the Mar- 
$m a$, though slight, will produce severe pain; similarly, the disorders localized in the Marma Sthana. Hence, they should be treated with great care and effort. ${ }^{2}$ Most of the ancient texts of Ayurveda had given importance to Marma and explained 107 Marma in a separate chapter.
The Lohitaksha marma is one among the Shakhagta Marma it is located above the Urvi Marma and below the Vankshana in the lower limb and in upper limb it is located above the Bahwi and below the Kaksha and injury leads to paralysis due to blood loss

Table 1: Description of Lohitaksha Marma

\begin{tabular}{|l|l|}
\hline Classification & Details \\
\hline Shadanganusara (Gross division of body in to six regions) & Shakhagatamarma \\
\hline Sankhyataha (Based on Number) & 4 (2 in upper limb and 2 in lower limb) \\
\hline Pramanataha (Based on measure) & $1 / 2$ anguli $(0.96 \mathrm{~cm})$ \\
\hline Rachanataha (Based on structure) & Sira marma \\
\hline Parinamataha (Based on prognosis) & Vaikalyakara marma \\
\hline ViddhaLakshana (Based on traumatic effect) & Paralysis due to blood loss \\
\hline
\end{tabular}

\section{Review of Literature}

Vyutpatti of Marma Shabda (Etymology)

The origin of the word Marma is seen in various texts as given below Amarakosha explains that the word Marma is derived from Sanskrit term Mru+Manin or mru Pranathyage. It means that which causes death or death like miseries ${ }^{3}$.

Shabdhakalpadruma describes Mru + Sarvadhatubhyo Manin. It also mentions Marma as Sandhi Sthanam or Jeeva Sthanam. ${ }^{4}$

Vachaspathya says that the word Marman is taken from Mri Dhatu, adding Maneen Pratyam, Mru Maneen, which means Jeeve Sthana or Sandhi Sthana. ${ }^{5}$ According to Sanskrit-English dictionary of Sir M. Monier-Williams, Marma means mortal spot, Vulnerable point, any open or exposed or weak or sensitive part of the body. ${ }^{6}$

The Vaydyaka Shabdha Sindhu as explains Marma Sthana as Jeeva Sthana. ${ }^{7}$

\section{Derivation of Marma}

1. Marma means that which kills. ${ }^{8}$

2. The vital spots that which causes death. ${ }^{9}$

3. That which cause Upahata to Anga is called as Marma. ${ }^{10}$

\section{Definition of Marma}

Acharya Susruta has defined Marma as the site where there is a conglomerate of Mamsa, Sira, Sna$y u$, Sandhi and Asthi. Especially Prana dwells at these sites. ${ }^{11}$ According to Astanga Sangraha, any part of the body where the uneven pulsations/reflex are elicited and pressure over that part causes pain, is called as Marma. ${ }^{12}$ Narahari the author of $R a$ janighantu defined Marma as the seat of life. ${ }^{13}$ Acharya Caraka has opined that it is the site of Chetana, so the sense of pain will be more in this region compared to other parts of the body. ${ }^{14}$ Ashtanga Hridaya has defined Marma as the site where Mamsa, Sira, Snayu, Asthi, Sandhi and Dhamani confluence. It is also said that the sites which are painful, tender and show unbearable throbbing pain after injury is considered as Marma. ${ }^{15}$ Bhavaprakasha has defined Marma as the meeting place of Mamsa, Sira, Snayu, Asthi and Sandhi where Prana or life resides. ${ }^{16}$

\section{Marma And Fundamental Components of The Body}

Panchamahabhuta (Prithvi, Ap, Tejo, Vayu and Akasa) and Atma constitute the living body. Nirvikara Atma/Chetana becomes Vikarayukta when it comes in contact with Panchamahabootatmaka Shareera. In a living being the state when the three Dosha are functioning normally, the Agnis, the Dhatu and Mala function accordingly and if its Atma, Indriya and Mana are pleasant the state is defined as health ${ }^{17}$. The life is sustained by Prana which is incorporated at the site of Marma. Susruta 
has given a broad meaning to the word Prana. Shareera Dosha that is Soma (Kapha), Maruta (Vata), Teja (Pitta) and Manasika Dosha that is Satva, Raja and Tama in the Marma. So, if the Marma gets injured all the Dosha gets vitiated. Agni, Soma, Vayu, Satwa, Rajah, Tamah, Bhuthatma and Panchendriyas are called as components of Prana. It engulfs all basic factors that sustain life. Agni sustains life by Parinama, Soma by Poshanam, Vayu by Chalanam (conduct, regulate and integrate all functions). Satwa, Raja, Tama by converting themselves into Manas. Panchendriya sustain by sensory perceptions. This is the core of Marma concept Acharya Susruta classified Marma into Agneya, Soumya and Vayavya, which is also indirectly related with the Tridosha. As Agni Guna is predominant, the delicate Avayavas disintegrate easily. Soma by its Sthira and SheetaGuna resists the destructive action of Agni. Vayu causes severe pain

\section{DISCUSSION}

The term Lohitaksha is comprising Lohita + Aksha words. Term Lohita is synonymous of Rakta. The word Aksha is derived from 'Kshee Dhatu' i.e., KsheeKsheeyate' means sort of loss/deterioration. In the term Aksha, letter 'A' is joined as Upasarga, so the meaning of word Aksha is "excessive." Eventually the meaning of word Lohitaksha is taken as excessive bleeding. ${ }^{18}$ Generally Marma is composed of five fundamental structures (MarmaVastu) i.e.,

Mamsa, Sira, Snayu, Asthi and Sandhi. Among these, structural, functional and pathological point of view, one may be very dominant therefore the symptoms exhibited after trauma will depend upon the involvement of that particular. Lohitaksha Marma belongs to Sira Marma group. On the basis of literature study, it is revealed that Lohitaksha Marma is mainly composed of Axillary artery and its branches, Axillary vein with its tributaries in relation to upper limb and in case of lower limb the femoral artery and its branches. As per the references available from the Samhita, location of the Lohitaksha Marma in the lower limb is said to be above the Urvi Marma and below the Vankshana Sandhi, at the root of the Uru.
So, in the upper limb it should be understood as the Lohitaksha Marma is located above Bahvi Marma and below Kaksha Sandhi, at the root of the Bahu. The location of Lohitaksha Marma is not precisely mentioned but it can be understood on the basis of distal and proximal landmark. Here the Vankshana Sandhi is to be correlated to the hip joint. Uru Moola can be understood in terms of either, inguinal fold or angle between the neck and shaft of the femur because head of the femur is involved in the articulation of hip joint. Hip joint is lying $1.2 \mathrm{cms}$ below the inguinal ligament and just below the joint there is angulation between neck and shaft of femur. On the basis of these features and classical description the location of Marma can be exacted between hip joint and neck shaft angle of femur. In these mentioned areas mainly femoral artery, vein with femoral sheath and femoral nerve is seen. In case of upper limb Kaksha Sandhi is to be correlated with the shoulder joint. Bahu Moola can be understood in terms of surgical neck of humerus. Above the surgical neck there find the articulation between head of humerus and glenoid cavity of scapula. On the basis of features and classical description the location of Marma can be exacted between the shoulder joint and surgical neck of humerus. In above mentioned area mainly axillary artery, axillary vein and cords of infraclavicular part of brachial plexus are located. The injury effect of Lohitaksha Marma is mentioned as there will be Marana and Pakshaghata or Saktisada due to Rakta Kshaya. Rakta is considered as one among the Dasha Pranayatana. ${ }^{19}$ The Rakta is the Moola of the Shareera. It does the Dharana of the Shareera. The Rakta nourishes the further Dhatus. So, loss of Rakta will lead to death. Sushruta Samhita mentions one should do the Samrakshana of the Rakta and it is known as the Jeeva. ${ }^{20}$ That may be the reason why even though the Lohitaksha Marma is the Vaikalyakara Marma, in the Viddha Lakshana of this Marma, Marana is mentioned. Vascular injuries of the extremities remain a major cause of limb amputation and death, if not treated early and properly. ${ }^{21}$ Severe haemorrhage from any of the major vessels will lead to the haemorrhagic shock. The Pakshaghata may be caused by the ischemia or due to the injury of the 
cords and branches of the brachial plexus/femoral nerve. Axillary and subclavian vascular injuries constitute less than $5 \%$ of all vascular trauma but are associated with morbidity and mortality rates ranging from $3 \%$ to $33 \%$. Concurrent brachial plexus injuries contribute greatly to the morbidity rate of thoracic outlet vascular trauma..$^{22}$ The meaning of the Marana can be understood as Localised ischemia due to the lack of the blood supply can be understood as Marana. The other Viddha Lakshana is Pakshaghata. The Pakshaghata can be considered as the paralyzed part. The Pakshaghata may be due to the ischemia, where is a chance of paralysis of that particular limb, due to haemorrhage. The early symptoms of the limb ischemia are there will be pain, muscle tenderness, sensory and motor loss.

\section{CONCLUSION}

Considering the literature related to The Lohitaksha Marma is situated above the BahviMarma and below the Kaksha Sandhi (shoulder joint) in case of the upper limb. The Bahumoola is considered as the surgical neck of the humerus in case of the upper limb. In the lower limb the site of Lohitaksha Marma is above the Urvi Marma and below the Vankshana Sandhi. The anatomical structures to be considered under the Lohitaksha Marma in the lower limb are part of the femoral artery where the origin of profunda femoris is seen along with accompanying femoral vein and a part of femoral nerve. In the upper limb the structures are third part of the axillary artery where the three branches arise along with the accompanying vein. The Pakshaghata is considered as pertaining to that particular limb, which is injured, caused due to increased blood loss leading into ischemia and paralysis or due to the injury of the surrounding nerves. Marana is considered in three ways i.e., localized death of the tissues due to ischemia or death of a person due to thrombus dislodged from the site of Marma causing pulmonary embolism and also due to excessive loss of blood causing shock or severe pain causing Marana Sadrishya Duhkha.

\section{REFERENCES}

1. Acharya YT. Shareera Sthana chapter 6 verse 26 Sushruta Samhita with Nibhandha sangraha commentary of Dalhan acharya. Reprint ed. Varanasi (India): ChaukambhaSankritSansthan;2010.;p.55.

2. Sharma SP. Shareera Sthana chapter 7 verse 24 Astanga Sangraha with Sashilekha Sanskrit commentary of Indu. $2^{\text {nd }}$ ed. Varanasi (India): ChaukambhaOrientalia;2008; p.326.

3. Shastri H. Amarakosha of Amarasimha. 4th ed. Varanasi (India): Choukambha Sanskrit Sansthan; 2006.p.656

4. RKD Bahadur. Shabdakalpadruma. 3rd ed. Varanasi: Chaukhambha Sanskrit Series; 2002. Vol 3.p.641.

5. Taranatha T. Vachaspathyam, 3rd ed. Varanasi: Chaukhambha Sanskrit Series; 1970. Vol 6.p. 4738.

6. Williams M. A Sanskrit- English Dictionary, 2nded. New Delhi: Bharatiya Granth Niketan; 2007.p.791.

7. Kaviraja Shree Nagendranatahsena. Vaydyakashabda Sindhu, 4th ed. Varanasi: Chaukambha Orientalia; 1999.p.789.

8. Acharya Y.T. Sushruta Samhita with Nibhandhasangraha commentary of Dalhanacharya. Reprint ed. Varanasi (India): Chaukambha Sankrit Sansthan; 2010.p.369.

9. Sharma SP. Astanga Sangraha with Sasilekha Sanskrit commentary of Indu.2nd ed. Varanasi (India): Chaukambha Orientalia; 2008.p.323

10. Paradakara HSS. Ashtanga Hridayam with Sarvanga Sundaram commentary of Arunadutta and Ayurveda Rasayana of Hemadri. Reprint ed. Varanasi (India): Chaukhambha Sanskrit Orientalia; 2010.p.409.

11. Acharya Y.T. Sushruta Samhita with Nibhandhasangraha commentary of Dalhanacharya. Reprint ed. Varanasi (India): Chaukambha Sankrit Sansthan; 2010. p.371.

12. Sharma SP. Astanga Sangraha with Sasilekha Sanskrit commentary of Indu.2nd ed. Varanasi (India): Chaukambha Orientalia; 2008.p.323

13. Tripady I.D. Rajanighantu of Narahari. Varanasi: Chaukhambha Krishnadas Academy; p.586.

14. Acharya J.T. Charaka Samhita with Ayurveda Deepika commentary of Chakrapani Datta. Reprinted. Varanasi (India): Chaukhamba oriental; 2011.p.713.

15. Paradakara HSS. Ashtanga Hridayam with Sarvanga Sundaram commentary of Arunadutta and Ayurveda Rasayana of Hemadri. Reprint ed. Varanasi (India): Chaukhambha Sanskrit Orientalia; 2010. p.413. 
16. Mishra B, Vaisya R. Bhavaprakasha of Bhava mishra with Vidyotini Hindi commentary. 11th ed. Varanasi: Chaumkhambha publications; 2004.p.65.

17. Acharya Y.T. Sushruta Samhita with Nibhandhasangraha commentary of Dalhanacharya. Reprint ed. Varanasi (India): Chaukambha Sankrit Sansthan; 2010. p.75.

18. Pandit M, Marma Namakaran Ka Ek Adhyan, Dissertation. Nagpur: Nagpur University; 2008.p.62-63.

19. Acharya J.T. Charaka Samhita with Ayurveda Deepika commentary of Chakrapani Datta. Reprinted. Varanasi (India): Chaukhamba oriental; 2011.p.181.

20. Acharya Y.T. Sushruta Samhita with Nibhandhasangraha commentary of Dalhanacharya. Reprint ed. Varanasi (India): Chaukambha Sankrit Sansthan; 2010. p.66.

21. Topal AE, Eren MN, Celik Y. Lower extremity arterial injuries over a six-year period: outcomes, risk factors, and management. Vascular health and risk management. 2010 December; 6: 1103-10.

22. Hyre CE, Cikrit DF, Lalka SG, Sawchuk AP, Dalsing MC. Aggressive management of vascular injuries of thoracic outlet. Journal of vascular surgery. 1998 May; 27: 880-85.

\section{Source of Support: Nil \\ Conflict of Interest: None Declared}

How to cite this URL: Rahul Kumar Gupta: A Comprehensive Study On Lohitaksha Marma. International Ayurvedic Medical Journal \{online\} 2020 \{cited December, 2020\} Available from: http://www.iamj.in/posts/images/upload/5346 5350.pdf 